AN INTRODUCTION TO BUILDING SERVICES 


\title{
AN INTRODUCTION TO BUILDING SERVICES
}

Christopher A. Howard

\author{
MPhil, DipQS, FRICS
}

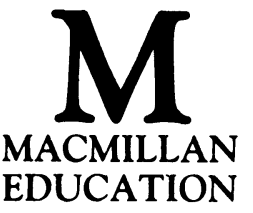


All rights reserved. No reproduction, copy or transmission of this publication may be made without written permission.

No paragraph of this publication may be reproduced, copied or transmitted save with written permission or in accordance with the provisions of the Copyright Act 1956 (as amended), or under the terms of any licence permitting limited copying issued by the Copyright Licensing Agency, 33-4 Alfred Place, London WC1E 7DP.

Any person who does any unauthorised act in relation to this publication may be liable to criminal prosecution and civil claims for damages.

First published 1988

Published by

MACMILLAN EDUCATION LTD

Houndmills, Basingstoke, Hampshire RG21 2XS

and London

Companies and representatives

throughout the world

British Library Cataloguing in Publication Data

Howard, Christopher A.

An Introduction to building services. -

(Macmillan building and surveying).

1. Buildings - Environmental engineering

I. Title

696

TH6021

ISBN 978-0-333-43462-8

ISBN 978-1-349-09259-8 (eBook)

DOI 10.1007/978-1-349-09259-8

\section{Series Standing Order}

If you would like to receive future titles in this series as they are published, you can make use of our standing order facility. To place a standing order please contact your bookseller or, in case of difficulty, write to us at the address below with your name and address and the name of the series. Please state with which title you wish to begin your standing order. (If you live outside the United Kingdom we may not have the rights for your area, in which case we will forward your order to the publisher concerned.)

Customer Services Department, Macmillan Distribution Ltd Houndmills, Basingstoke, Hampshire, RG21 2XS, England. 
To my family

for their patience and

understanding throughout the production

of this work 


\section{CONTENTS}

Preface

Acknowledgements

List of figures

$x i$

1 COLD WATER INSTALLATIONS - SUPPLY AND DISTRIBUTION

The demand for cold water; supplies to low rise dwellings; mains pressure and tank pressure water; pipe fittings; supplies to high rise buildings; systems of mains assistance; sanitary appliances

\section{HOT WATER GENERATION AND DISTRIBUTION}

Methods of hot water generation; electric immersion heaters; boiler generation methods; direct and indirect cylinders; gas heaters; solar heating of water; the primatic method; unvented hot water installations

3 DRAINAGE ABOVE GROUND - DISPOSAL INSTALLATION PIPEWORK

Design criteria; flow patterns and pressure fluctuations; traps to appliances; siphonage effects; pipework arrangements

\section{DRAINAGE BELOW GROUND}

Types of discharge; classification of systems; design criteria; gullies and traps; forms of access; pipe materials jointing and bedding; drain termination

\section{SPACE HEATING OF BUILDINGS}

Low pressure hot water systems; one pipe, two pipe, and microbore systems; choice of fuel; fuel burning and delivery; combustion and pollution; medium and high pressure hot water systems; steam heating; ducted warm air; solar heating; group and district heating; heat recovery

\section{SPECIALIST SERVICES - MECHANICAL VENTILATION, AIR CONDITIONING, LIFT} INSTALLATIONS, ESCALATORS AND FIRE FIGHTING INSTALLATIONS

Mechanical ventilation - an introduction to the principles considered in design; alternative arrangements; fans; ducting outlet grilles, diffusers and dampers; noise generation and transfer

Air conditioning - background to design; basic components of a system; refrigeration; heat pumps; dual duct systems; variable volume

Lift installations - design considerations; constructional features; electric lifts; hydraulic lifts; lift call systems

Escalators - design considerations; typical layouts; fire control

Fire fighting installations - active and passive fire control; equipment; sprinklers; hoses; riser systems

\section{ELECTRICAL INSTALLATIONS}

National distribution; incoming supplies; units of electricity; small domestic installations; lighting, power and equipment power; larger installations; single and three phase deliveries

\section{GAS INSTALLATIONS}

Town and natural gas; safety considerations; connection of supplies; air for combustion; flues to low rise and multi-storey buildings; flame failure protection 
9 REFUSE DISPOSAL

The nature of waste; building geometry and collection; solid waste disposal; storage and direct collection; chutes; on-site treatment of waste; pipeline collection systems; pneumatic and waterborne systems

10 THE INTEGRATION OF SERVICES INTO BUILDINGS

Design and service integration; structural accommodation methods; walkways; crawlways; vertical ducts; floor trenches; non-structural accommodation methods; suspended ceilings; raised floors; trunking; fire precautions

11 SERVICE EQUIPMENT FOR EXTERIOR MAINTENANCE

The influence of building geometry and material arrangement on exterior maintenance; external access equipment - temporary and permanent

Appendix A: Services - A brief introduction to the economics of choice

Appendix B: The interpretation of drawn information - symbols associated with the components of service installations 


\section{PREFACE}

This book applies a principles approach throughout and is designed to meet the needs of those whose responsibility is the administration, control, and inspection of buildings. The parameters on which the text is based include an appreciation of the choice options available, identification of major components, and an insight into operation.

Many in authoritative positions of management require a broad understanding of services but do not need the detailed design knowledge which would be required by an engineer. Survey inspections for maintenance, repair and safety may also require this approach.

To complement each section within the text, many references are made to appropriate British Standards, Codes of Practice and the Building Regulations 1985.

Christopher A. Howard 


\section{ACKNOWLEDGEMENTS}

The author acknowledges the willingness of many manufacturers within the building industry to permit the reproduction of text illustrations of their products.

Special thanks are given to Elizabeth and Paul Hodgkinson for the excellence of their artwork. 


\section{LIST OF FIGURES}

1.1 Cold water supply - the service pipe 2

1.2 Cold water installation - two storey domestic $r$

1.3 A typical ball-valve assembly 2

1.4 Stopcocks and gate valves 3

$\begin{array}{lll}1.5 & \text { Capillary and compression pipe fittings } & 4\end{array}$

$\begin{array}{ll}1.6 & \text { Changing the pipe direction }\end{array}$

$\begin{array}{lll}1.7 & \text { Capillary pipe fittings } & 4\end{array}$

$\begin{array}{lll}1.8 & \text { The pneumatic system of cold water delivery } & 5\end{array}$

1.9 The header storage system $\quad 6$

1.10 An enclosed tank system $r$

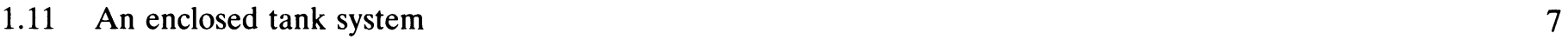

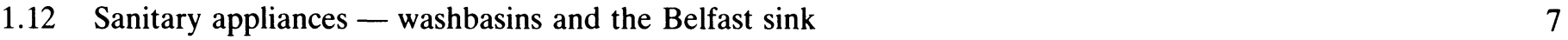

1.13 Types of WC $r$

1.14 Types of urinal $r$

$\begin{array}{ll}1.15 \\ \text { Bib, pillar and mixer taps } & 8\end{array}$

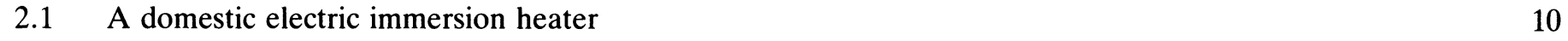

$\begin{array}{ll}2.2 & \text { A variable demand electric immersion cylinder } \\ 2.30\end{array}$

2.3 Composite plumbing packages - electric hot water heating and cold water storage 11

2.4 Direct hot water generation by open-fire back boiler 11

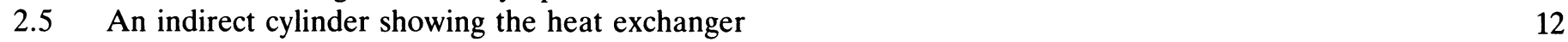

\begin{tabular}{ll}
2.6 & Indirect hot water generation \\
\hline & 12
\end{tabular}

$\begin{array}{lll}2.7 & \text { Solar generation of hot water } & 13\end{array}$

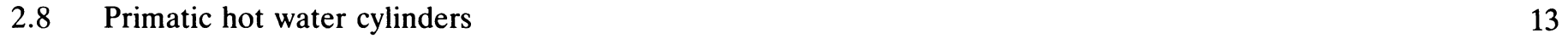

$\begin{array}{ll}2.9 & \text { The unvented hot water system } \\ 3.14\end{array}$

3.1 Flow patterns in near horizontal and vertical pipes 16

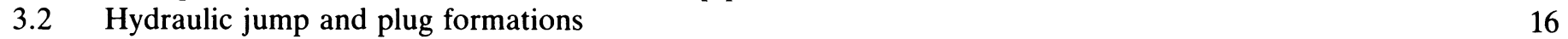

$\begin{array}{lll}3.3 & \text { Types of trap } & 17\end{array}$

\begin{tabular}{ll}
3.4 & Combined trap and overflow to baths \\
\hline
\end{tabular}

$\begin{array}{ll}3.5 & \text { Self-siphonage in a waste pipe } \\ 3.6 & 17\end{array}$

\begin{tabular}{lr}
3.6 & Induced siphonage in a waste pipe \\
\hline
\end{tabular}

$\begin{array}{llr}3.7 & \text { Back-pressure percolation } & 18\end{array}$

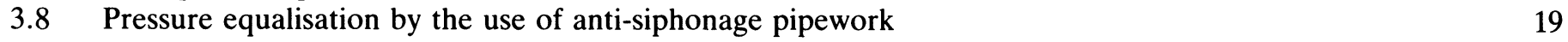

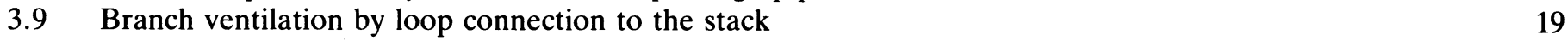

3.10 The principle of the Grevak anti-siphonage bottle trap $\quad 19$

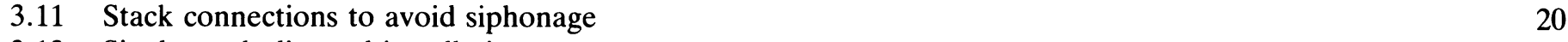

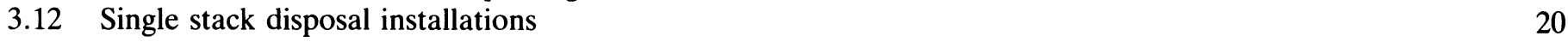

3.13 One pipe disposal installations $\quad 21$

3.14 Two pipe disposal installations 21

4.1 Drains, private sewers and public sewers 22 
4.2 One and two piece gullies 24

4.3 Horizontal and vertical back inlet gullies 24

$\begin{array}{llr}4.4 & \text { A typical road gully } & 24\end{array}$

4.5 A mud-intercepting gully 25

4.6 The petrol interceptor $r$

$\begin{array}{llr}4.7 & \text { Traditional brick manholes } & 25\end{array}$

4.8 Branch connections at the manhole 26

4.9 Shallow and deep manhole profiles 26

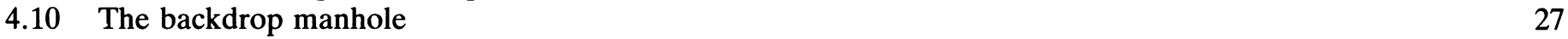

4.11 A pre-cast concrete manhole $\quad 27$

4.12 A plastic inspection chamber 28

$\begin{array}{lr}4.13 \text { A rodding eye detail } & 28\end{array}$

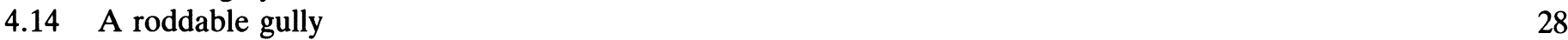

4.15 Socket and spigot, and plain ended pipe joints 29

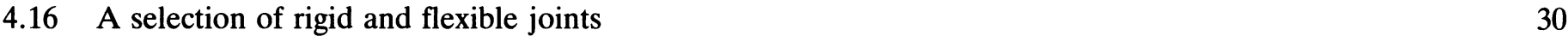

4.17 Traditional concrete supports to pipes $\quad 30$

4.18 Movement joints in concrete pipe encasement 31

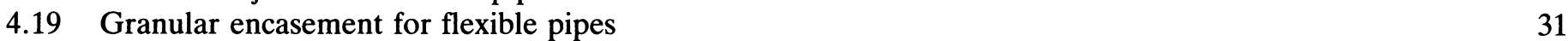

$5.1 \quad$ The one pipe ring and ladder systems 33

5.2 The one pipe drop and parallel systems $\quad 34$

5.3 The two pipe drop and parallel systems 35

5.4 The two pipe upfeed and high-level return systems 35

$\begin{array}{ll}5.5 & \text { The principle of the microbore system } \\ 5\end{array}$

$\begin{array}{lll}5.6 & \text { Automatic stoking devices } & 37\end{array}$

$\begin{array}{lll}5.7 & \text { Oil atomisation delivery jets } & 37\end{array}$

5.8 Fan-assisted removal of combustion gases $\quad 38$

5.9 The basic components of a steam heating system $\quad 39$

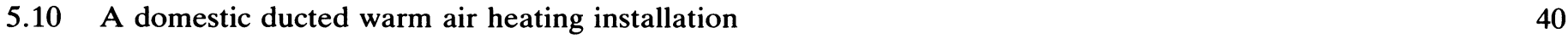

5.11 Solar air heating $\quad 42$

5.12 Solar water heating $\quad 42$

5.13 The three pipe group heating arrangement 42

5.14 The four pipe group heating arrangement 43

5.15 Plate and thermal wheel heat exchangers 43

5.16 The run around coil heat exchanger $\quad 44$

$\begin{array}{ll}6.1 & \text { Plenum ventilation for a factory building } \\ 6\end{array}$

$\begin{array}{lll}6.2 & \text { Classification of ventilation systems } & 46\end{array}$

6.3 The use of duct vanes at corners 4

$\begin{array}{llr}6.4 & \text { Rectangular pressed metal ducts } & 48\end{array}$

6.5 Air delivery grilles and diffusers $\quad 48$

6.6 Duct dampers $\quad 49$

$\begin{array}{lll}6.7 & \text { The component parts of an air conditioning system } & 50\end{array}$

$\begin{array}{ll}\text { 6.8 The basic components of a refrigerator } & 51\end{array}$

6.9 The dual duct air conditioning system $\quad 52$

6.10 A constant-volume air mixer inlet unit $\quad 52$

6.11 An induction air conditioning unit $\quad 52$

6.12 A typical lift shaft $r$

6.13 Single wrap and 3:1 lift roping $\quad 54$

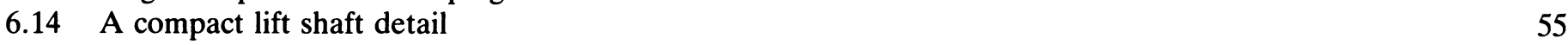


6.15 Escalators - typical installation dimensions 56

6.16 Escalators serving successive floors 56

6.17 Escalators - the use of fire roller shutters 57

6.18 The distribution pipe network for a typical sprinkler installation 58

6.19 A quartzoid sprinkler head 59

6.20 Dry and wet riser systems 59

$7.1 \quad$ Voltages - three-phase four-wire supplies 61

7.2 A busbar conductor 61

7.3 Encased PVC conductors 62

7.4 Electricity entry into the building - the domestic consumer board 63

7.5 A diagrammatic representation of the electrical installation of a dwelling 63

7.6 The tap-in or jointing method for a lighting circuit 64

7.7 Two-way switching for lights 64

7.8 Multi-storey single-phase risers from a three-phase service mains 65

7.9 A multi-storey rising three-phase supply with single-phase branch connections 65

8.1 Gas service pipe entry above and below ground 67

8.2 Gas service pipe entry via a meter box 67

8.3 Gas supplies to multi-storey buildings 68

8.4 The gas meter with pressure governor 68

8.5 Water gauge tests for gas piping 68

8.6 A balanced flue detail to a room-sealed appliance 69

8.7 The 'U-duct' principle 69

8.8 Discharges from open fire flues - terminal details 70

8.9 Pipe open flues for gas appliances 70

8.10 A typical gas flue block system 71

8.11 The 'SE-duct' flue 71

8.12 The shunt-duct flue arrangement 72

9.1 Solid waste disposal systems 74

9.2 The component parts of a refuse chute 74

9.3 The sink receiver of the Garchey system 75

9.4 A sink grinder 75

10.1 The walkway duct 76

10.2 The crawlway duct 77

10.3 Internal and external access vertical ducts 77

10.4 Floor trenches 78

10.5 Types of suspended ceiling 78

10.6 A typical support suspension framework for a suspended ceiling 79

10.7 Exposed grid and concealed grid types of jointed suspended ceiling 79

10.8 A jack post for a deep cavity raised floor system. 79

$10.9 \quad$ In-situ and purpose-made shallow cavity raised floors 80

10.10 Skirting trunking in pressed metal 80

10.11 Trunking embedded in the floor screed 80

11.1 The influence of design shape on perimeter and wall area 82

11.2 Access towers for maintenance 83

11.3 Cantilever support for a temporary access cradle 84

11.4 Fixed davits for the suspension of temporary cradles 84

11.5 Moving trolley suspensions for temporary cradles 85

11.6 The steel-framed timber cradle 85 
11.7 A power cradle suspended from a powered trolley

A.1 The balance between initial costs and running costs 